\title{
Understanding the Purchase Behavior of Young Indonesian Hijaber on Fashion Product
}

\author{
Indarti $^{1^{*}}$, Yuhri Inang Prihatina ${ }^{2}$, Imami Arum Tri Rahayu ${ }^{3}$, Li-Hsun Peng $^{4}$ \\ ${ }^{123}$ Home Economic Department, Universitas Negeri Surabaya; \\ ${ }^{2}$ Creative Design Department, National Yunlin University of Science \& Technology, Taiwan \\ *Corresponding authorE-mail: indarti@ unesa.ac.id
}

\begin{abstract}
The interest in understanding the relationship between Islam and consumption has been increased recently. Indonesia is a country where more than $80 \%$ of the population is Muslim, has a great Muslim market potential especially in Islamic fashion. The purpose of this study is to explore the involvement and purchase behavior of young Indonesian Hijaber on fashion products. An online survey was completed by a total of 308 young Indonesian Hijaber. The description of buying behavior was analyzed by mean. To test the hypothesis, we applied regression analysis by using SPSS. The results indicate that the most fashion item bought by young Indonesian Hijabers are clothing, they shop every month, and they spend Rp200.000-500.000 for shopping fashion product. Instagram is the most favorite sources to get information about new fashion products (89.3\%). This finding shows that fashion involvement has significant positive impact on purchase behavior of young Indonesian Hijabers. The results of the study help to suggest various marketing and retailers formulate product positioning strategies that create more value for consumer segments especially young people in Indonesia.
\end{abstract}

Keywords: fashion involvement, purchase behavior, fashion products, Islam and consumption, young Indonesian Hijaber, instagram

\section{INTRODUCTION}

Indonesia has the largest Muslim population in the world. The young generations are increasingly wearing hijab. Hijab in this research refers to the headscarf or veil covering Muslim women's hair with proper and modest apparel. In Indonesia, Muslim women (Muslimah) who dress stylishly while conforming to the hijab is called Hijaber. In Malaysia, they called Hijabista [1]. According to Galadri (2012), Muslim women wear hijab to express their identity and spiritual faith through their religious and cultural practice. He mentioned if we see women wearing hijab, the first mind that comes up is that women belong to Islam and has strong believe in religion and culture that is why they are wearing hijab [2]. Hijab and modest fashion are popular phenomena that become trend in Indonesia as expression of cultural identity and communication [3]. The majority of Muslim countries allows Muslim women to express their individuality through the latest fashion trend with a variety of style and accessories called 'Islamic cosmopolitanism' [4]. Muslim women nowadays have more fashion and choices of style than ever before, in accordance the rise of Muslim fashion media, blog, retailers, and designers [5]. The present hijab fashion trends attempt to modernize a modest style while maintaining the essence of cultural views, it provides a refreshing contemporary feeling of elegance and vitality, and it creates trends and new styles for Muslim women who are blending fashion with their Islamic faith [6]. Lewis (2013) mentioned that ICTs are used extensively and creatively by young Muslim to form 'empowerment', to put positioning of Young Muslim women in Indonesia. This shows how Hijabers have gained an important position in the analysis of contemporary Muslim society in Southeast Asia.

The interest in understanding the relationship between Islam and consumption has been increased recently. Indonesia is a country where more than $80 \%$ of the population is Muslim, has a great Muslim market potential especially in Islamic fashion. Wilson (2013), called Islamic Marketing as both a concept and lived experienced, manifest in the competitiveness exchange of commoditized thoughts, object, feeling, and action between engaged individuals and collectives [7]. Hijab fashion is related to belief and religion that are the central issues in any consumer behavior research. Religion is an important cultural factor to study because it is one of the most universal and influential social institutions that have a significant influence on people's attitudes, values and behaviors at both the individual and societal levels [8]. The role religion plays in shaping consumer behavior [9]. Religion affects consumers' lifestyles that in turn affect consumer decision-making behavior [10]. Understanding the nature of consumer buying behavior has been a key component of research in marketing for some considerable time. 
The previous research mentioned potential impacts of religion on luxury consumption attitudes and personal values appear to be moderated by the global consumer culture [11]. Asian consumers devoured media commentary, drew inspiration from female celebrities, and treated information-seeking and discussion of luxury fashion brands with friends as a serious and enjoyable pursuit [12]. In Malaysia, materialism, fashion clothing involvement and religiosity are significant drivers of fashion clothing purchase involvement [13], dressing style, fashion motivation, fashion uniqueness and sources of fashion knowledge positively influence fashion consciousness and indirectly influence hijab fashion consumption [14], there is a significant relationship between factors of brand loyalty (price, promotion, service quality, store environment, and style) with Muslimas fashion brand loyalty [15].

Fashion involvement has been regarded as an important research topic in consumer research. Product involvement is commonly defined as a consumer's enduring perceptions of the importance of the product category based on the consumer's inherent needs, values, and interests [16]. Consumers with high product involvement experience constant high involvement with a particular product category [17]. It has been established that the level of involvement determines the depth, complexity, and extensiveness of cognitive and behavioral processes during the consumer choice process [18].

Fashion involvement has been discussed and utilized to examine fashion clothing in a number of prior studies. Aron (2000) tested four types of involvement: (a) product involvement; (b) purchase decision involvement; (c) advertising involvement and (d) consumption involvement, his study presented an alternate approach to the conceptualization and measurement of four important types of involvement that will aid in better understanding consumer behavior [19]. Aron (2004) examined the relationships between gender, age, self-monitoring, materialism, fashion clothing consumption motives, and fashion clothing involvement. He found that materialism and symbolic motives have a significant effect on respondent's level of involvement in fashion clothing however age and gender had differing effects on purchase decision and product involvement [20]. Eun et al. (2006) examined the causal relationships among fashion involvement, positive emotion, hedonic consumption tendency, and fashion-oriented impulse buying in the context of shopping and found that fashion involvement and positive emotion had positive effects on consumers' fashion-oriented impulse buying behavior with fashion involvement having the greatest effect [21]. Hareem
(2011) examined Pakistan female consumer's buying behavior and found that status branding, brand attitude, paying premium for branded clothing, self-concept and reference groups have positive effects on female consumer buying behavior [22].

This purpose of this study to explore the involvement and purchase behavior of young Indonesia Hijabers on fashion product. This research conducted in Indonesia, the largest Muslim population in the world. Wearing hijab, as the dress code of Muslim women, affects consumers' lifestyles that in turn affect consumer decision-making behavior [10]. In this paper also seeks the favorite items of fashion product, the frequency of shopping, budget for shopping trip, and information sources as reference of young Indonesian Hijabers. This study provides valuable insight to retailers on the most favorite items of fashion product and information sources, also the frequency and budget for shopping. Understanding the purchase behavior of young Indonesian Hijabers will be helpful for emphasis marketing strategy.

\section{METHOD}

\section{Instrument Development}

We developed 2 kinds of instruments. First, multiplechoice as objective assessment to select the best answer from the choices offered as a list of the research market. The questions are about demographic and description of buying behavior that was developed of the modification from previous studies from Gul et al. [23] that described in Table 1. Demographic information was collected for, age, marital status, education, occupation, and monthly income/allowance. The second instrument, we adopted the measures mainly in the fields of fashion product involvement and buying behavior. The respondents were asked to rate the questions on a five-point Likert scale. Product involvement measured three items on a five-point rating scale ( $1=$ strongly disagree, 5 strongly agree), extracted from the fashion clothing involvement as suggested by Aron [20] such as "Fashion clothing is important to me", "I think about fashion clothing a lot" and "I am very interested in fashion clothing". Purchase behavior concerns a consumer's action to purchase apparel products. We assessed purchase behavior by using five items measured on a five-point rating scale ( $1=$ strongly disagree, 5 strongly agree), developed by Lam and Yee [23] such as "I am usually the first to buy the latest fashion", "I usually shop in trendy shop"," I shop for clothing frequently", "I spend long hours on shopping", and "I spend a lot on clothing". 
Table 1. The Multiple Choice Question of Buying Behavior

\begin{tabular}{cll}
\hline No. & \multicolumn{1}{c}{ Multiple Choice Questions } \\
\hline 1 & What items of fashion products did you buy often? \\
& $\bigcirc \quad$ Clothing \\
& $\circ \quad$ Hijab \\
& $\bigcirc \quad$ Accessories \\
& $\bigcirc \quad$ Bags \& shoes \\
& $\circ \quad$ Cosmetics
\end{tabular}

2 How often do you shop for fashion products?

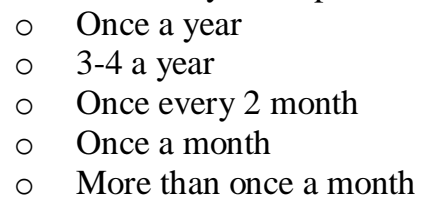

3 How much do you spend per shopping trip?

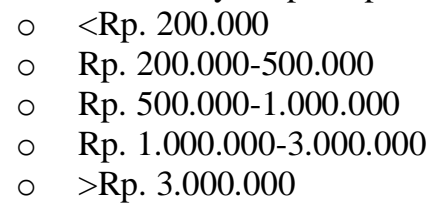

4 How do you get information about new fashion products?

$\begin{array}{ll}\circ & \text { Online advertising } \\ \circ & \text { Fashion blog } \\ \circ & \text { Instagram } \\ \circ & \text { Facebook } \\ \circ & \text { Magazine } \\ \circ & \text { Recommendation of friends } \\ \circ & \text { TV/film } \\ \circ & \text { Window display/sores } \\ \circ & \text { others }\end{array}$

\section{Sampling and Data Collection}

The data set come from an online administrated survey of a convenience sample of young Indonesian Hijabers. The questionnaire was distributed since the middle of 2018 by Instagram. We select participants who look young on their photo profile and sent questioners randomly via personal message. Finally we obtained 308 answered questionnaires.

\section{Data Analysis}

The first data from objective assessment about description of buying behavior of young Indonesian Hijabers was analyzed by mean. We chose the higher mean to describe how the purchase behavior of young Hijabers.
In order to achieve the main purpose of the study and to test the hypothesis, we applied regression analysis by using SPSS. Reliability testing was conducted to assess the degree of consistency for the constructs in this study. Cronbach's alpha $(\alpha)$ is a measure commonly used to assess the internal consistency of a scale. A Cronbach's alpha $(\alpha)$ value that is greater than 0.7 is acceptable, thus demonstrating that the instrument is reliable. Table 2 provides an overview of the results of the reliability test. All of the constructs have a Cronbach's alpha value higher than the cutoff point of 0.7 . These results provide strong evidence that the instrument specifically designed for this study is highly reliable in acquiring consistent data. 
Table 2. Overview of Result of Reliability Test

\begin{tabular}{lc}
\hline \multicolumn{1}{c}{ Constructs } & Cronbach's Alpha \\
\hline Fashion involvement & 0.847 \\
Purchase Behavior & 0.851 \\
\hline
\end{tabular}

\section{RESULTS AND DISCUSSION}

\section{Demographic Analysis}

Among a total 308 of Young Indonesian Hijabers, $68.2 \%$ were $19-24$ years old, $18.8 \%$ were $25-29$ years old, $7.5 \%$ were $30-35$ years old, and $5.5 \%$ were below 18 years old. The majority of the respondents were single $(80.1 \%)$. Concerning education, $63.4 \%$ were currently in bachelor degree, and $17.8 \%$ were student in Senior High School. The majority of occupations were salaried (48.1\%) and student (46.5\%). Regarding average monthly income levels, 53\% were above $\mathrm{Rp}$. 3.000.000, and $25.2 \%$ were between Rp. 3.000 .000 and Rp. 5.000.000.

Table 3. Demographic Profile of Respondents

\begin{tabular}{llcc}
\hline \multicolumn{1}{c}{ Criteria } & N & $\%$ \\
\hline Age & $<18$ & 17 & 5.5 \\
& $19-24$ & 210 & 68.2 \\
& $25-29$ & 58 & 18.8 \\
Marital status & $30-35$ & 23 & 7.5 \\
Education & Single & 246 & 80.1 \\
& Married & 60 & 19.5 \\
& Senior High School & 55 & 17.8 \\
& Diploma & 42 & 13.6 \\
& Bachelor & 196 & 63.4 \\
& Master & 16 & 5.2 \\
Occupation & Doctoral & - & - \\
& Student & 145 & 46.5 \\
& Salaried & 150 & 48.1 \\
Monthly Income & Housewife & 17 & 5.4 \\
& $<$ Rp. 3.000.000 & 160 & 53 \\
& Rp. 3.000.000-5.000.000 & 76 & 25.2 \\
& Rp. 5.000.000-7.000.000 & 22 & 7.3 \\
& Rp. 7.000.000-10.000.000 & 19 & 6.3 \\
& $>$ Rp. 10.000.000 & 25 & 8.3 \\
\hline
\end{tabular}

\section{Descriptive Analysis}

What items of fashion products did you buy often?

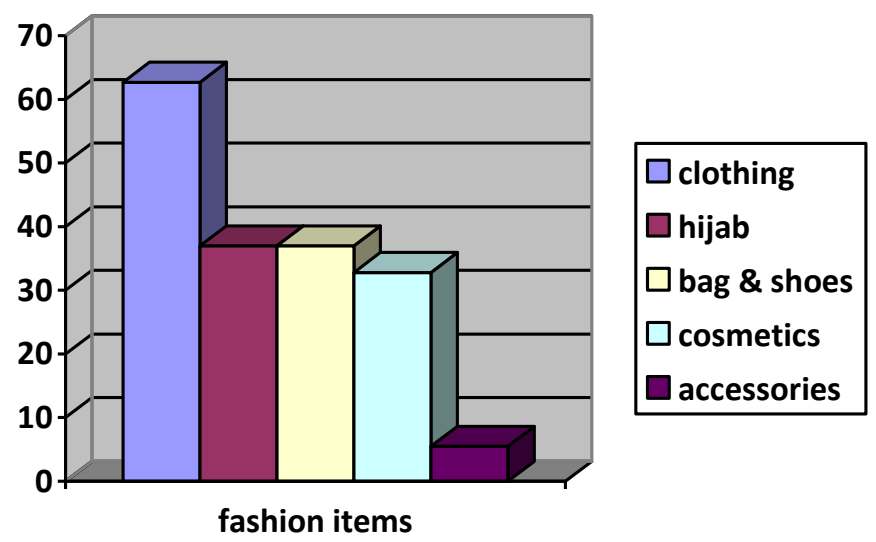

Figure 1. The Favorite Fashion Items 
The result shows clothing is the higher items (62.7\%) that were bought by young Indonesian Hijabers. Hijab and bag $\&$ shoes were the second favorite (37\%). Cosmetics were $32.8 \%$, and the less favorite was accessories $(5.5 \%)$.

How often do you shop for fashion products?

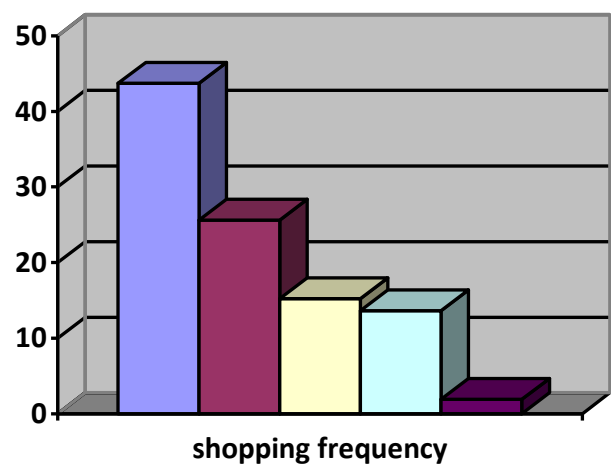

\begin{tabular}{|l|}
\hline once a month \\
$\square$ once in 2 month \\
$\square$ more then once a month \\
$\square 3$ to 4 a year \\
$\square$ once a year
\end{tabular}

Figure 2. The Shopping Frequency

The result shows the most of shopping frequency of young Indonesian Hijabers is once a month (43.7\%). Another frequency is once in 2 months $(25.6 \%)$, more than once a month (15.2\%), 3 to 4 a year $(23.6 \%)$ and once a year $(1.9 \%)$

How much do you spend per shopping trip?

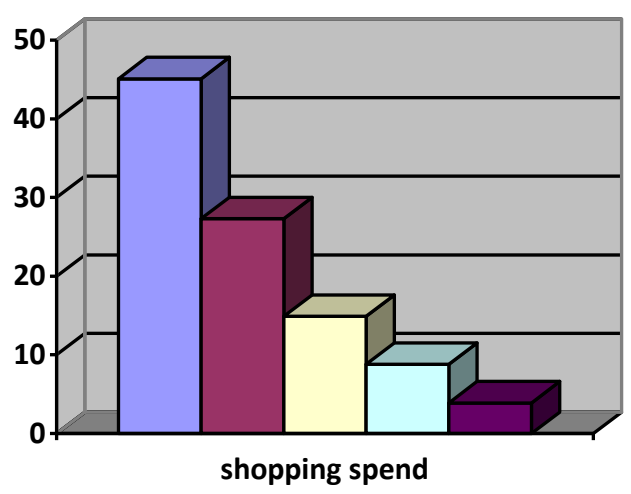

\begin{tabular}{|l|}
$\square$ 200.000-500.000 \\
$\square$ 500.000-1.000.000 \\
$\square$ no more 200.000 \\
$\square$ 1.000.000-3.000.000 \\
$\square$ more than 3.000.000
\end{tabular}

Figure 3. The Budget of Shopping

The result shows the budget spend on shopping is Rp.200.000-500.000 (45.1\%), Rp. 500.000-1.000.000 (27.3\%), no more than Rp.200.000 (14.9\%), Rp.1.000.000-3.000.000 (8.8\%) and more than Rp.3.000.000 (3.9\%).

How do you get information about new fashion products? 


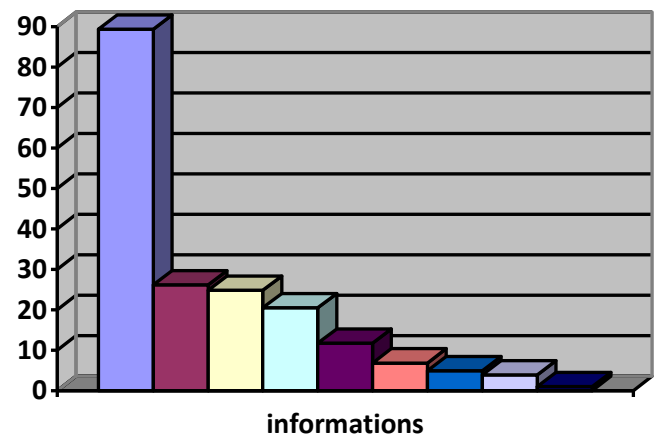

\begin{tabular}{|l|}
\hline Instagram \\
$\square$ online advertisement \\
$\square$ friend recommendation \\
$\square$ fashion blog \\
$\square$ window display/ stores \\
$\square$ TV/film \\
$\square$ magazine \\
$\square$ Facebook \\
$\square$ Others
\end{tabular}

Figure 4. The Favorite Information Sources

The result shows the most favorite sources is from Instagram (89.3\%), online advertisement (261\%), friend recommendations (24.8\%), fashion blog 20.5\%), window display/stores (11.7\%) and less favorite are TV/film, magazine, and Facebook.

\section{Hypothesis Testing}

The hypothesis is fashion involvement has a positive impact on buying behavior of young Indonesia Hijabers. Before testing the hypothesis the properties of the scale were examined. The data were initially examined for dispersion and central tendency via means and standard deviation. Table 4 provides descriptive statistics for the constructs in this study.
The descriptive statistics reveal that there is no major violation of regression assumption.

We applied a regression analysis to analyze the hypotheses proposed in this study by using SPSS. The hypothesis is supported (see Table 5) because fashion involvement has a significant effect on purchase behavior of young Indonesian Hijabers $(\beta=0.595$, $p<$ $0.05)$.

Table 4. Mean and Standard Deviation of the Study Constructs

\begin{tabular}{lcc}
\hline \multicolumn{1}{c}{ Constructs } & Mean & $\begin{array}{l}\text { Standard } \\
\text { Deviation }\end{array}$ \\
\hline Fashion involvement & 4.106 & 0.678 \\
Purchase Behavior & 2.897 & 0.867 \\
\hline
\end{tabular}

Table 5. Overview of Result of Regression Analysis

\begin{tabular}{lll}
\hline \multicolumn{1}{c}{ Hypothesis } & Coefficient & Supported? \\
\hline $\begin{array}{l}\text { Fashion involvement has a positive impact on } \\
\text { purchase behavior of young Indonesian } \\
\omega_{\text {inahare }}\end{array}$ & 0.595 & Yes \\
\hline
\end{tabular}

From demographic, the age of participants is young, most of them $(68.2 \%)$ is $19-24$ years old. Most of them are a student $(48.1 \%)$ and salaried $(46.5 \%)$. Their monthly income/allowance is low above Rp.3.000.000 $(53 \%)$. However, their fashion involvement is high (mean $=4.1$ from five-point rating scale). Young Indonesian Hijabers are interested and think about fashion a lot. Fashion is important to them. According to Martin and Bush (2000), young consumers are more concerned with trends than any other age group [24]. The results indicate that the most item bought by young Indonesian Hijabers is clothing. They shop every month for fashion products. They spend Rp200.000-500.000 for shopping and their sources to get information about new fashion products is Instagram $(89.3 \%)$. Instagram has become the most popular s-commerce site among young people [25]. The number of active monthly Instagram users had reached 1 Billion and 500 million daily active users [26]. Instagram is social networking sites (SNS) has increased among young people, and adoption among top brands [27].

This finding shows that fashion involvement has a significant positive impact on purchase behavior of young Indonesian Hijabers. Fashion clothing is important to Young Indonesia Hijabers. They think a lot and interested in fashion clothing. This finding is similar to Eun et al. (2006) that fashion involvement had positive effects on consumers' fashion-oriented impulse buying behavior [21]. Fashion clothing involvement is significant drivers of fashion clothing purchase involvement [28]. Fashion involvement emerged as the most significant and dominant factor that influence the consumers' intention to adopt fashion [29]. 
This study suggests that young Indonesian Hijabers who are more involved in fashion product show a higher tendency to engage in purchase behavior. Previous literature assessed that product involvement is “A consumer's enduring insight into the importance of the product category based on the consumer's intrinsic needs, values, and interests" [30]. Understanding the purchase intention of consumers is crucial because their final buying behavior can be predicted from their intention [31].

\section{CONCLUSION}

The results indicate that the most fashion item bought by young Indonesian Hijabers are clothing, they shop every month, and they spend Rp200.000-500.000 for shopping fashion product. Instagram is the most favorite sources to get information about new fashion products (89.3\%). This finding shows that fashion involvement has significant positive impact on purchase behavior of young Indonesian Hijabers.

\section{REFERENCES}

[1] Hassan, Siti Hasnah, and Harmimi Harun. "Factors influencing fashion consciousness in hijab fashion consumption among hijabistas." Journal of Islamic Marketing 7.4 (2016): 476-494.

[2] Galadari, Abdulla. "Behind the veil: Inner meanings of women's Islamic dress code." The Journal of Interdisciplinary Social Sciences 6.11 (2012): 115-125.

[3] Peng, Li Hsun. "Modern hijab style in Indonesia as an expression of cultural identity and communication." 2016 International Conference on Applied System Innovation (ICASI). IEEE, 2016.

[4] Potts, J. (2009), Lifting the Veil on Fashion Filling the Gaps between Modesty and Fashion Apparels, the Ohio State University, Columbus, $\mathrm{OH}$.

[5] Ghani, A.A. (2011), "Asian Muslim Women's fashion history", Aquila, May/June.

[6] Lewis, Reina, ed. Modest Fashion: Styling bodies, mediating faith. IB Tauris, 2013.

[7] Wilson, Jonathan AJ, and John Grant. "Islamic marketing-a challenger to the classical marketing canon?." Journal of Islamic Marketing 4.1 (2013): 7-21

[8] Mokhlis, Safiek. "Relevancy and measurement of religiosity in consumer behavior research." International Business Research 2.3 (2009): 75-84.

[9] Mathras, Daniele, et al. "The effects of religion on consumer behavior: A conceptual framework and research
The Islamic fashion industry is one of the key areas where Islamic entrepreneurialism becomes mainstream fashion industries in global market. The finding in this study has important implications for practitioners who seek opportunities in the Islamic fashion industry. The results of the study help to suggest various marketing and retailers formulate product positioning strategies that create more value for consumer segments especially young people.

agenda." Journal of Consumer Psychology 26.2 (2016): 298-311.

[10] Delener, Nejdet. "Religious contrasts in consumer decision behaviour patterns: their dimensions and marketing implications." European Journal of Marketing 28.5 (1994): 36-53.

[11] Nwankwo, Sonny, Nicolas Hamelin, and Meryem Khaled. "Consumer values, motivation and purchase intention for luxury goods." Journal of retailing and consumer services 21.5 (2014): 735-744.

[12] Wu, Meng-Shan Sharon, et al. "Luxury fashion brands: factors influencing young female consumers' luxury fashion purchasing in Taiwan." Qualitative Market Research: An International Journal 18.3 (2015): 298-319.

[13] Rahman, Mahfuzur, et al. "Towards a better understanding of fashion clothing purchase involvement." Journal of Islamic Marketing 9.3 (2018): 544-559.

[14] Hassan, Siti Hasnah, and Harmimi Harun. "Factors influencing fashion consciousness in hijab fashion consumption among hijabistas." Journal of Islamic Marketing 7.4 (2016): 476-494.

[15] Mohamed, Rozita Naina, Norzehan Abu Bakar, and Bahtiar Mohamad. "Factors Influencing the Supply Chain of Muslimas Fashion (Hijabs) on Brand Loyalty." Int. J Sup. Chain. Mgt Vol 8.3 (2019): 1018.

[16] De Wulf, Kristof, Gaby OdekerkenSchröder, and Dawn Iacobucci. "Investments in consumer relationships: a cross-country and cross-industry exploration." Journal of marketing 65.4 (2001): 33-50.

[17] Ha, Young, and Sharron J. Lennon. "Effects of site design on consumer emotions: role of product involvement." Journal of Research in Interactive Marketing 4.2 (2010): 80-96.

[18] Chakravarti, Amitav, and Chris Janiszewski. "The influence of macro-level motives on consideration set composition in novel purchase situations." Journal of Consumer Research 30.2 (2003): 244-258.

[19] O'Cass, Aron. "An assessment of consumers product, purchase decision, advertising and consumption involvement in fashion 
clothing." Journal of Economic Psychology 21.5 (2000): 545-576.

[20] O'Cass, Aron. "Fashion clothing consumption: antecedents and consequences of fashion clothing involvement." European Journal of Marketing 38.7 (2004): 869-882.

[21] Joo Park, Eun, Eun Young Kim, and Judith Cardona Forney. "A structural model of fashion-oriented impulse buying behavior." Journal of Fashion Marketing and Management: An International Journal 10.4 (2006): 433-446.

[22] Zeb, Hareem, Kashif Rashid, and M. Bilal Javeed. "Influence of Brands on Female Consumer's Buying Behavior in Pakistan." International Journal of Trade, Economics and Finance 2.3 (2011): 225.

[23] Lam, Yuki WK, and Rachel WY Yee. "Antecedents and consequences of fashion consciousness: an empirical study in Hong Kong." Research Journal of Textile and Apparel 18.4 (2014): 62-69.

[24] Martin, Craig A., and Alan J. Bush. "Do role models influence teenagers' purchase intentions and behavior?." Journal of consumer marketing 17.5 (2000): 441-453.

[25] Che, Jasmine WS, Christy MK Cheung, and Dimple R. Thadani. "Consumer purchase decision in Instagram stores: The role of consumer trust." Proceedings of the 50th Hawaii International Conference on System Sciences. 2017.
[26] C, Smith. "250 Amazing Instagram Statistics and Facts for 2019" (September, 2019). Available at: https://expandedramblings.com/index.php/i mportant-instagram-stats/

[27] Casalo, Luis V., Carlos Flavián, and Sergio Ibáñez-Sánchez. "Antecedents of consumer intention to follow and recommend an Instagram account." Online Information Review 41.7 (2017): 1046-1063.

[28] Rahman, Mahfuzur, et al. "Towards a better understanding of fashion clothing purchase involvement." Journal of Islamic Marketing 9.3 (2018): 544-559.

[29] Salleh, Muhammad Asyraf Mohd, et al. Factors that influence consumers' intention to adopt apparel fashion among University Malaysia Kelantan students. Diss. Faculty of Entrepreneurship and Business, 2016.

[30] De Wulf, Kristof, Gaby OdekerkenSchröder, and Dawn Iacobucci. "Investments in consumer relationships: a cross-country and cross-industry exploration." Journal of marketing 65.4 (2001): 33-50.

[31] Bai, B., Law, R., \& Wen, I. (2008). The impact of website quality on customer satisfaction and purchase intentions: Evidence from Chinese online visitors. International journal of hospitality management, 27(3), 391-402. 